University of Nebraska - Lincoln

DigitalCommons@University of Nebraska - Lincoln

Space, Cyber, and Telecommunications Law

Program Faculty Publications

Law, College of

2011

\title{
The Origins of Authorisation: Article VI of the Outer Space Treaty and International Space Law
}

Frans G. von der Dunk

University of Nebraska - Lincoln, fvonderdunk2@unl.edu

Follow this and additional works at: https://digitalcommons.unl.edu/spacelaw

Part of the Air and Space Law Commons, and the International Law Commons

von der Dunk, Frans G., "The Origins of Authorisation: Article VI of the Outer Space Treaty and International Space Law" (2011). Space, Cyber, and Telecommunications Law Program Faculty Publications. 69.

https://digitalcommons.unl.edu/spacelaw/69

This Article is brought to you for free and open access by the Law, College of at DigitalCommons@University of Nebraska - Lincoln. It has been accepted for inclusion in Space, Cyber, and Telecommunications Law Program Faculty Publications by an authorized administrator of DigitalCommons@University of Nebraska - Lincoln. 
Published as chapter 1 of National Space Legislation in Europe: Issues of Authorisation of Private Space Activities in the Light of Developments in European Space Cooperation, Studies in Space Law, volume 6 (Frans G. von der Dunk, editor), pages 3-28. Leiden, The Netherlands: Martinus Nijhoff Publishers. Copyright $\odot 2011$ Koninklijke Brill NV, Leiden, The Netherlands. Used by permission.

\title{
The Origins of Authorisation: Article VI of the Outer Space Treaty and International Space Law
}

\author{
F. G. von der Dunk
}

\section{Private Activity but Public Responsibility}

The issue of authorisation of private space activities, the key theme of the present book, ultimately goes back to the principled political disagreements in the 50s and 60s between the two (then) superpowers in space, the United States and the Soviet Union, on the proper role of other entities than states in space activities. The Soviet Union, true to its communist ideology, was squarely against any private activities in most economically relevant areas of society, but certainly so in an area of such strategic concern as outer space. ${ }^{1}$ By contrast, the United States throughout its existence has usually presented itself as the champion of private enterprise, an approach also transpiring in its space policies.

When, following the establishment of the Committee on the Peaceful Uses of Outer Space first as an Ad Hoc Committee ${ }^{2}$ then as a more permanent one, ${ }^{3}$ serious discussion began on drafting a coherent legal framework for activities in outer space, this dichotomy became one of the bones of contention. Whereas the Soviet Union would insist that there should be no room for private entities within that legal framework being developed, the United States principally did not wish to close the door on them legally speaking.

At the same time, the realities at the dawn of the space age were quite clear. The - for the time incredibly advanced-levels of technology required to go into outer space, the costs and risks associated with that adventure, and the two areas originally considered the only possible beneficiaries of space activities and space technology (the military and politicostrategic domain in terms of the Cold War rivalry and the scientific domain) ensured that for some time to come realistically speaking states were the only potential actors in outer 
space - and to be more precise: only a handful of states were actually able and willing to take the relevant burdens upon themselves.

As a matter of fact, also the United States itself did not envisage private entrepreneurs to actually go into outer space on short notice so readily. Even when developing a national legal framework for the use of satellites in the context of telecommunications, the first sector of space which was to draw private entrepreneurs into the field, the United States would develop a government-driven monopoly system, establishing Comsat Corporation for the purpose. ${ }^{4}$

The mutual need, even desire, to arrive at a workable solution in order not to put the whole process of arriving at a comprehensive legal regime for space activities at risk, in the end gave rise to a compromise that is best captured by: "private activity but public responsibility."

\section{Resolution 1962(VIII) and Private Space Activities}

The first legal document dealing fundamentally with that compromise was Resolution 1962(VIII) of 13 December 1963..$^{5}$ The Resolution captured in several paragraphs the general focus on global public interests in outer space which neither the United States nor the Soviet Union had an issue with. Thus, in drafting it the General Assembly was "inspired by the great prospects opening up before mankind as a result of man's entry into outer space," recognized "the common interest of all mankind in the progress of the exploration and use of outer space for peaceful purposes," and believed "that the exploration and use of outer space should be carried on for the betterment of mankind and for the benefit of States irrespective of their degree of economic or scientific development." 6

Such sentiments were also transformed into operative provisions in the actual Principles contained in the Resolution. ${ }^{7}$ Notably, Principle 2 claimed that "outer space and celestial bodies are free for exploration and use by all States on a basis of equality and in accordance with international law," whereas Principle 4 provided that "the activities of States in the exploration and use of outer space shall be carried on in accordance with international law, including the Charter of the United Nations, in the interest of maintaining international peace and security and promoting international cooperation and understanding." 8 This focus on the participation of states and the public interests involved at the outset limited any potential role for private enterprise, which generally speaking becomes active in a certain area or field first and foremost for its own, usually commercial reasons.

Most pertinent to the compromise, however, was Principle 5. The Soviet Union in the end was willing to mitigate its point of view to the extent that whomever would happen to be active in outer space, one state or another should be held responsible for its activities. ${ }^{9}$ The United States and its allies for their part accepted such a formal lack of absence of legal personality for private entities on the international plane since at least the principled legality of their future involvement in actual space activities was not precluded, as long as under the umbrella of a state's responsibility.

This compromise found its way into the 1963 Resolution, where it was phrased as follows: 
States bear international responsibility for national activities in outer space, whether carried on by governmental agencies or by non-governmental entities, and for assuring that national activities are carried on in conformity with the principles set forth in the present Declaration. The activities of non-governmental entities in outer space shall require authorization and continuing supervision by the State concerned. When activities are carried on in outer space by an international organization, responsibility for compliance with the principles set forth in this Declaration shall be borne by the international organization and by the States participating in it. ${ }^{10}$

In sum: private activities in outer space, read the activities of private entities in outer space, were legal but always as subject to the responsibility on the international plane of (at least) one state, which also was under the concurrent obligation to authorize and continuously supervise such activities - "private activity but public responsibility," indeed.

\section{The Outer Space Treaty and Private Space Activities}

When, four years after Resolution 1962(VIII), the Outer Space Treaty ${ }^{11}$ transformed most obits principles - considered binding by many as customary law anyway-into formally binding treaty obligations, Article VI was to copy Principle 5 almost word by word. In full namely, Article VI provided:

States Parties to the Treaty shall bear international responsibility for national activities in outer space, including the Moon and other celestial bodies, whether such activities are carried on by governmental agencies or by non-governmental entities, and for assuring that national activities are carried out in conformity with the provisions set forth in the present Treaty. The activities of nongovernmental entities in outer space, including the Moon and other celestial bodies, shall require authorization and continuing supervision by the appropriate State Party to the Treaty. When activities are carried on in outer space, including the Moon and other celestial bodies, by an international organization, responsibility for compliance with this Treaty shall be borne both by the international organization and by the States Parties to the Treaty participating in such organization.

Also in the case of the Outer Space Treaty, the aforementioned fundamental secondary role of private space entrepreneurs was embedded in more general rules and principles propounding the public interests in space and space activities, focusing (presumably at least) on scientific and strategic uses. Thus, "the exploration and use of outer space, including the Moon and other celestial bodies, shall be carried out for the benefit and in the interests of all countries, irrespective of their degree of economic or scientific development, and shall be the province of all mankind" 12 ; and 
States Parties to the Treaty shall carryon activities in the exploration and use of outer space, including the Moon and other celestial bodies, in accordance with international law, including the Charter of the United Nations, in the interest of maintaining international peace and security and promoting international cooperation and understanding. ${ }^{13}$

Also the other operative Articles throughout spoke of "States" as being entitled to undertake certain activities, conversely disallowed to undertake them or obliged to abide by certain principles. ${ }^{14}$

The Outer Space Treaty entered into force rapidly, within nine months of the conclusion of the process of drafting, and as of 1 January 2008 enjoys the ratifications of 98 states plus the signatures of 27 more states. ${ }^{15}$ Since, moreover, those states comprise all of the states important from the perspective of space activities and space law, ${ }^{16}$ the Outer Space Treaty rapidly came to be recognized as the "Magna Charta" for outer space, laying the groundwork for all legal rules pertaining to the conduct of space activities that were to follow. As a consequence, the drafting and acceptation of Article VI of the Outer Space Treaty as a key provision of that treaty established the concept of general state responsibility in the special area of outer space activities in a specific fashion as a cornerstone of international space law. ${ }^{17}$

\section{Interpreting Article VI of the Outer Space Treaty}

One main novel feature of Article VI stood out with reference to the role of private enterprise in this context. Contrary to the version of the concept applicable under general international law, where "direct state responsibility" only pertained to acts somehow directly attributable to a state and states could only be addressed for acts by private actors under "indirect," "due care"/"due diligence" responsibility, ${ }^{18}$ Article VI made no difference as to whether the activities at issue were the state's own ("whether such activities are carried on by governmental agencies" ...) or those of private actors (... "or by non-governmental entities"). The interests of the Soviet Union in ensuring that, whomever would actually conduct a certain space activity, some state or other could be held responsible for its compliance with applicable rules of space law to that extent had prevailed.

However, the general acceptance of Article VI as cornerstone of the Outer Space Treaty unfortunately was far from the end of the story. Partly, this was the consequence of key principles being left undefined.

\subsection{The Concept of "National Activities"}

A major example thereof concerns the concept of "national activities," as determining the scope of state responsibility in particular in terms of categories of private activities. The concept was defined properly or authoritatively neither by the Outer Space Treaty itself, nor by follow-up legal documents of international space law, nor by general public international law. ${ }^{19}$ The only, partial, exception was the Moon Agreement, the limited acceptance of which (certainly when it comes to the major space-faring nations, also in 
Europe) however serves to cast further doubt on the value of its contribution to the present discourse. 20

Nevertheless, the Moon Agreement does provide some interesting formulations. Firstly, it more or less repeats Article VI, when it provides that "States Parties to this Agreement shall bear international responsibility for national activities on the Moon, whether such activities are carried on by governmental agencies or by nongovernmental entities, and for assuring that national activities are carried out in conformity with the provisions set forth in this Agreement." ${ }^{21}$ Secondly, it immediately proceeds by stating that "States Parties shall ensure that nongovernmental entities under their jurisdiction shall engage in activities on the Moon only under the authority and continuing supervision of the appropriate State Party." 22 This phrase could be interpreted as equating "national activities" at least as far as undertaken on the moon with "activities undertaken under the jurisdiction" of the state concerned, to the extent of being conducted by nongovernmental entities.

Further interesting clues in this respect may be glanced from two UN Resolutions containing general principles applicable to major specific categories of space activities - while their status as General Assembly Resolutions causes them to be legally nonbinding per se they may still be helpful in these general structural issues, as any lack of consensus largely applied to the substance of some of the principles. ${ }^{23}$

The first of those pertained to the Resolution on direct television broadcasting by means of satellites, UNGA Resolution 37/92. ${ }^{24}$ Principle 8 provides for state "responsibility for activities in the field of international direct television broadcasting by satellite carried out by them or under their jurisdiction." 25 Like under the Moon Agreement therefore, responsibility is directly and explicitly linked to jurisdiction, supporting the conclusion that under Article VI of the Outer Space Treaty "national activities" would likely have to be read in particular with reference to "jurisdiction" - the Resolution indeed requests states to "authorize such activities by persons and entities under its jurisdiction." 26

The second Resolution of interest here is that on remote sensing, UNGA Resolution 41/65. ${ }^{27}$ Here, states are to bear international responsibility "for their activities." ${ }^{28}$ The phrase "their" is even less unequivocal than the phrase "national" used in Article VI of the Outer Space Treaty. However, as Principle XIV of the Resolution provides, the latter also includes nongovernmental entities within its scope, so the legal effect of this Principle is similar to that of Article VI when it comes to defining the categories of private entities for which a specific state is internationally responsible.

Still, the consequence of a lack of unequivocal guidance on the international level regarding the proper interpretation of "national activities" was that on the one hand experts differed considerably in their respective interpretations, whereas on the other hand those states which considered it necessary to implement Article VI, consciously or unconsciously (likely the latter more often than the former) picked their own choice in determining the scope of their national space laws and acts.

As to the experts themselves, whose opinions gained considerable relevance from the absence of any harmonised state practice, essentially three schools of thought could be discerned..$^{29}$

The first focused on the word "national" in "national activities." This approach took the adjective "national" to refer to the noun "national," in other words to a person or entity 
with the nationality of the state concerned. Pointing furthermore to the fact that Article IX of the Outer Space Treaty in a somewhat comparable context-of acting responsibly in outer space, in this specific instance by being aware of potential detrimental effects of its activities and consequently informing other states that might be concerned thereof-juxtaposed activities of a state to those of "its nationals," 30 the experts concerned interpreted "national activities" as referring to "activities of nationals." In other words: a state was to be held international responsible for space activities conducted by its nationals-obviously including private companies and other legal persons.

The second group of experts tried to make up for an apparent inconsistency in the Treaty, that between dealing with international responsibility as per Article VI and international state liability per Article VII in terms of attribution. ${ }^{31}$ Since the latter had focused on the state(s) fundamentally involved in the launching of a space object that caused damage (in a fourfold fashion), the concept of "national activities" in the former should be interpreted as referring to those activities for which the state concerned qualified as the "launching State." 32 While the result would, indeed, be that liability under Article VII and responsibility under Article VI would be attributed on the same footing, this solution overlooked several complicating factors.

Most importantly, responsibility focused on activities (not just on launch activities only), liability on (damage caused by) space objects where the launch served as the crucial trigger for attributing liability. For example, a satellite operator's state would be responsible under Article VI for satellite communication activities conducted in outer space and their consequences. In case the operator would have acquired the satellite involved by means of an in-orbit sale, however, its state would not have been involved in the launch of the satellite in any sense so as to trigger its liability under Article VII and the Liability Conventionsuch liability for damage caused by these activities would have rested upon (an)other state(s). Also, why would two different phrases have been used for the purpose of attribution if the drafters would have aimed at making the two concepts attributable along the same lines? 33

The third school of thought approaches the issue from a different angle. It does not look elsewhere in the Outer Space Treaty for guidance on the true meaning of "national activities," but views that term in relation to the obligations further provided by Article VI of "authorization and continuing supervision" of "the activities of nongovernmental entities in outer space" against a background of general international law. Noting that, from a logical perspective, it would make most sense for states to be held legally responsible for those activities in respect of which they had the legal tools available to control them, and hence give substance to such responsibilities, and that such was the approach also taken by general international law towards the scope of state responsibility, this school claimed that "national activities" should be read as referring to those activities which, in one way or another, fell under the jurisdiction of the state(s) to be held responsible for them. Moreover, this focus on (applicability of) jurisdiction as the key criterion for determining the scope of "national activities" is corroborated at least by the framing of state responsibility in the context of the Moon Agreement and UNGA Resolutions 37/92 and 41/65 as discussed above. 
In the context of space, this reference to jurisdiction would boil down to a threefold attribution. The first and second methods of attribution would be through the traditional general public international law concepts of "territorial jurisdiction" 34 and "personal jurisdiction" (jurisdiction over those persons, natural and legal, that enjoyed the nationality of the state concerned). ${ }^{35}$ In other words, to the extent that activities in outer space were conducted from a state's territory (elements of manned space flight operations excepted, all activities in outer space are still principally conducted from the Earth), that state should be held responsible since territorial jurisdiction gave it the legal tools to actually live up to such a responsibility. Similarly, to the extent that activities in outer space were conducted by a state's nationals (including private companies), that state should be held responsible for them as it had the principled legal tool of "personal jurisdiction" available for the purpose of controlling them.

That this approach meant that, in many cases, more than one state could be held responsible with regard to one and the same activity in outer space, should not be seen as an insurmountable obstacle. In general public international law, such issues of conflicting and competing jurisdiction continue to be prevalent, and legal instruments ranging from "extradition" 36 to forum non conveniens ${ }^{37}$ and diplomatic immunity, ${ }^{38}$ and of course general conflict of laws and private international law concepts, had been developed throughout the ages to properly deal with them.

Moreover, also under the two other approaches multiple states could become involved. In particular in today's corporate world, companies have ties with more than one state and their nationality nowadays even legally speaking may be a matter of debate-should it be only the place of incorporation that determines nationality, or also the headquarters, and/or main place of activity, and/or even the distribution of shareholders in terms of nationality? ${ }^{39}$ And the concept of the "launching State" itself, under the second school to be read into Article VI, itself was allowing for more than one state to qualify in the same instance-in many cases (a) state(s) different from the state(s) launching a space object was/were procuring its launch.

Effectively, the Outer Space Treaty itself had established an additional, third potential basis for states to exercise control over space activities, as a "State Party to the Treaty on whose registry an object launched into outer space is carried shall retain jurisdiction and control over such object, and over any personnel thereof, while in outer space or on a celestial body." 40 This specific and explicit application of quasi-territorial jurisdiction on the basis of registration of the spacecraft concerned should, under the third approach to "national activities," also mean states should be held responsible for activities involving space objects registered with them, since they are indeed able to legally give substance to such responsibility.

As indicated, the absence of any authoritative guidance on the proper scope of "national activities" left individual states, when considering full-fledged interpretation of Article VI of the Outer Space Treaty, on their own in determining such scope. While the issue of how the various existing national space laws have actually addressed this, is addressed more in depth in other contributions to this book, ${ }^{41}$ it can already be summarised at the outset that indeed such national implementation mechanisms widely differed regarding their respective scopes. 
This remaining uncertainty on how to interpret "national activities" also did not fail to affect the issue central to this book, of authorisation (and continuing supervision), since of course the extent to which states would feel compelled to undertake actual authorisation would largely depend upon the extent to which they foresaw a risk of being held internationally responsible for the activities at issue.

\subsection{The Concept of the "Appropriate State"}

Unfortunately, the main difference between Resolution 1962(XVIII) and the Outer Space Treaty was to exchange the phrase of "the State concerned," as the state upon whom the obligation to authorise and continuously supervise private space activities rested, for that of "the appropriate State." The former phrase rather unequivocally referred back to the state responsible (or at least one of the states responsible) as the one charged to authorise.

The insertion of "the appropriate State" in Article VI, however, immediately raised questions also beyond the fundamental issue of whether the explicit singular used in this context meant that, after all, a certain set of activities in outer space could only be attributed to one state at a time, or whether in cases where multiple states bore international responsibility there was just one of them to be considered "the [most] appropriate" one to be actually forced to exercise jurisdiction, to authorise, and to continuously supervise. ${ }^{42}$

Many various options were proposed for determining in any particular case the state that should be labelled the most appropriate one for the purpose of authorisation, ranging from the "launching State" of the space object involved (again in an effort to reconcile Article VI's responsibility clauses in terms of attributability with Article VII), to the state most closely involved in the activities to be authorised (which of course begged the question how to define such a criterion) or even to the state from whose territory the activities were mainly conducted (also a nod to Article VII, but this time with the realisation that activities in outer space under Article VI were not limited to those concerning the launch of space objects properly speaking).

From the perspective of the present book, all states that have taken up the issue of authorising national private space activities (however defined) have, explicitly or implicitly, considered themselves to be the "appropriate State" for precisely doing so. To the extent, furthermore, that any coherence or uniformity of approach could be determined amongst the national space laws or other appropriate mechanisms for authorisation these national mechanisms actually may serve as a customary law-interpretation, through state practice and opinio juris sive necessitatis, ${ }^{43}$ of this key clause of Article VI.

\subsection{The Relationship with other Key Clauses of the Outer Space Treaty}

Finally, a straightforward interpretation, application, and interpretation of Article VI was and is considerably complicated by its relationship with several other key clauses of the Outer Space Treaty. Whilst Article IX has been alluded to in this context, in essence it provided for a specific version of obligations to inform and consult with other states in case one's own (planned or ongoing) space activities could represent serious threats to activities of those other states, and to conduct one's own activities with some minimal form of regard for environmental interests. ${ }^{44}$ In other words, this clause provided one, albeit peculiar set 
of substantive obligations violation of which would incur the relevant state's responsibility under Article VI.

From a more structural point of view, especially Articles VII and VIII of the Outer Space Treaty should be briefly be addressed as playing a major role in determining how states would interpret and implement their responsibility under Article VI to authorise and otherwise appropriately deal with national space activities conducted by private enterprise. Those two Articles will therefore be briefly addressed in the next two sections.

\section{Article VII, Liability and Authorisation under Article VI}

Article VII of the Outer Space Treaty provides for a close corollary to the international state responsibility addressed by Article VI, through the concept of international liability for damage, as follows:

Each State Party to the Treaty that launches or procures the launching of an object into outer space, including the Moon and other celestial bodies, and each State Party from whose territory or facility an object is launched, is internationally liable for damage to another State Party to the Treaty or to its natural or juridical persons by such object or its component parts on the Earth, in air space or in outer space, including the Moon and other celestial bodies. ${ }^{45}$

The effort by certain scholars to "insert" the attribution of liability, as per the activity, procurement, territory, or facility of launch, into the concept of "national activities" has been referred to above. Also, the complex relationship, both in abstract and general terms and in the specific context of space law, between the concepts of "responsibility" and "liability," has already been noted. ${ }^{46}$

The key issue to be addressed is that liability in space law, as a form of general accountability intricately related to responsibility as another form of such accountability, without a doubt focuses on the potential for one state or group of states to claim compensation for damage caused by another state or group of states - and hence concerns potentially large sums of money easily to be visualised. Moreover, such liability includes private entities subsumed under those: the attribution of such liability as per Article VII of the Outer Space Treaty and Article I(c) of the Liability Convention ${ }^{47}$ takes place to one or more states regardless of any involvement of private entities in the causation of the damage or the manufacture, launch, or operation of the space object concerned. In other words: one state or another (or a number of states) will carry the international liability for space activities conducted by private companies.

It will be obvious therefore that for states concerned in more general terms with the obligation of Article VI to authorise national space activities undertaken by nongovernmental entities, attention will immediately be directed to ensuring that the aforementioned liability is, as far as considered necessary and possible, taken care of by such authorisation. Put differently, states will wish to exercise the control inherent in the concept of authorisation amongst others over those entities which by their activities may incur the international liability of those respective states. 
Of course, this was one reason behind the efforts to make the criterion for attribution of private companies for purposes of Article VI match those for purposes of Article VII (and the Liability Convention), effectively equating the concept of "national activities" to those sets of activities for which the state concerned would qualify (also) as "launching State."

Apart from the questions which arise following such an interpretation as pointed out before, however, this brings the issue of divergence between application of the concepts of "responsibility" and "liability" by the Outer Space Treaty back on the table, as it certainly also in pragmatic terms impinges on the issue of authorisation of private space activities under Article VI.

Summarising the consequences of the liability regime established under space law discussed before, four options for attributing liability exist. A state would be liable for damage caused by a space object manufactured, owned, launched, operated, marketed, sold and/or disposed of, as the potential target for authorisation, wherever that state qualifies as

1. the state that launched,

2. the state that procured the launch,

3. the state whose territory was used for the launch of, and/or

4. the state whose facility was used for the launch of the space object concerned. ${ }^{48}$

A complicating factor here, is whether "the state" should be read literally and narrowly as possibly referring only to a state, or whether it should more broadly be read as including cases where "its" companies actually undertake the launch, procure it, or offer their facilities for it. ${ }^{49}$ If the former interpretation is true, there would be no issue for "authorisation," properly speaking to that extent, since either a state incurs liability under any of these headings because it undertakes the activity concerned itself, or that activity is undertaken by a nongovernmental entity and hence does not possibly trigger the state's international liability (at least not under that heading). If the latter interpretation is true, however, a private company launching a space object may trigger its state's liability, and the same applies mutatis mutandis for private procurement and the use of private facilities, in which cases the state concerned would be interested in ensuring that the scope of its system of authorisation extends to such activities.

The criterion of "territory" is the odd one out here, in that it can never be referred to as being "of" a private entity, as international law reserves the term exclusively to the context of states. ${ }^{50}$ In other words, by definition private launches conducted from a state's territory trigger that state's liability under international space law-and would likely cause the liable state to exercise authorisation and supervision competences for the purpose. As has been noted elsewhere, this clause has provided a kind of "lock" on the system, ensuring that there could always be at least one state found liable on the international level for a completely privately conducted space activity causing damage..$^{51}$ That is, of course, until the Sea Launch consortium started launching from the high seas, where no territorial sovereignty applies. ${ }^{52}$

This evaluation of Article VII leads to the following systematic analysis, for the purpose of determining the interest of a particular state in establishing a system of authorisation applicable to the scenario at hand. 
Option 1 (in the broad interpretation) would make a state liable also in scenarios where its territorial jurisdiction may not allow the tool of authorisation to be effectively appliednamely if the private entity "that launches (. . .) an object into outer space," to use the phrasing of Article VII, undertakes such launching activities fundamentally from outside the state's territory. If such activities should nevertheless be seen as leading to the state's liability, the only realistic option here would be for the company to be of the nationality of that state-otherwise its launch activities should be allocated to a different state for the purpose of being subsumed under "the state that launches (...) an object into outer space." In other words: if the state concerned applies its authorisation regime not (only) on a territorial basis, but (also) on a personal basis, requiring any private operator with its nationality to be authorised regardless of where the launch is to be conducted, it can still cover also the scope of its possible liability under Article VII of the Outer Space Treaty and the Liability Convention.

Option 2 (again under the broad interpretation) presents even more difficulties from the present perspective, because of the additional vagueness stemming from the use of the term "procuring." ${ }^{53}$ In addition to the definition thereof being far from generally agreed upon, whatever "procurement" might actually turn out to be in essence it does not even concern an "activity in outer space" (to refer to the phrasing of Article VI); often-quoted efforts to define the concept of "procuring a launch" refer to "making it happen," "paying for it," or even "licensing it."

One may indeed wonder whether a national space law would be the proper place for including a requirement of authorisation before procurement should be allowed, in particular if wider interpretations of the concept are used (or expected to be used). For example in the United Kingdom the inclusion of procurement in a rather extended interpretation as an activity requiring a license under the applicable Act resulted in criticisms that this would mean that even a bank financing a satellite operation would be required to obtain such a license, including the undertaking of possible liability- and insurance-related obligations. 54

Still, one could argue that for any private party procuring a satellite launch to result in the liability of a particular state under Article VII of the Outer Space Treaty and the Liability Convention, that private party would either have to operate ("to undertake the procurement at issue") from the territory of that state or in its quality as being a national entity of that state-in which cases giving the authorisation regime a territorial respectively nationality-based scope would suffice for allowing that state to cover its potential liability thereby.

Option 3, the odd one out, results in few problems. Since it concerns the use of a state's territory for a launch, the resulting liability for that state can easily be subsumed under the territorial scope of any national authorisation regime developed in the context of Article VI's obligation.

Finally, once a private facility would come to be equated with a state's facility for the purpose of triggering Article VII and the Liability Convention, Option 4 may well require extension of the scope of the relevant national authorisation regime to privately owned facilities regardless of their location if the private owner is of the nationality of that state 
to provide full coverage in terms of international space law liability, since territorial jurisdiction would only cover such facilities if located in the territory of that state.

In conclusion, if states are interested in covering, through their authorisation regimes, also the possible liability they may incur-at least under the broad interpretation-as a consequence of private space (or adjacent: procurement!) activities, they would better establish an authorisation regime that does not only apply to such activities conducted in their territory, but also to such activities conducted by their nationals regardless of where that takes place.

\section{Article VIII, Registration, and Authorisation under Article VI}

Also Article VIII of the Outer Space Treaty has an intricate relation to Article VI, and hence should be investigated with a view to properly assessing the authorisation requirement resulting from the latter. Article VIII in relevant part provides: "A State Party to the Treaty on whose registry an object launched into outer space is carried shall retain jurisdiction and control over such object, and over any personnel thereof, while in outer space or on a celestial body."

The Registration Convention, generally considered as elaborating Article VIII of the Outer Space Treaty, ${ }^{55}$ further provides with regard to jurisdiction-more precisely, where more than one state could qualify as state of registration:

Where there are two or more launching States in respect of any such space object, they shall jointly determine which one of them shall register the object in accordance with paragraph 1 of this article, bearing in mind the provisions of article VIII of the Treaty on Principles Governing the Activities of States in the Exploration and Use of Outer Space, including the Moon and Other Celestial Bodies, and without prejudice to appropriate agreements concluded or to be concluded among the launching States on jurisdiction and control over the space object and over any personnel thereof. ${ }^{56}$

For the purposes of dealing with authorisation of private space activities, it is important first to note that "jurisdiction," as essentially the sovereign right to control private persons and entities by juridical means and notably including the competence to authorise or refuse authorisation, is to be "retained" under Article VIII of the Outer Space Treaty. The use of the word "retain" points to jurisdiction which somehow already exists-in other words, to national jurisdiction and territorial jurisdiction, as the two traditional generic forms of national jurisdiction accepted under public international law. ${ }^{57}$ In other words, these already existing forms of jurisdiction are extended to outer space-more precisely to particular space objects present therein-by means of registration, and could therefore be exercised on board of such space objects. ${ }^{58}$

Thus, Article VIII provides essentially for a third legal instrument available to individual states, next to territorial and nationality-based jurisdiction, to exercise legal control

over space activities conducted by private players in case they qualify as "launching States" of a space object involved in such activities and use that qualification to legitimately 
serve as state of registration - and to thus create their own entitlement to exercise jurisdiction.

To the extent that this may reinforce an interpretation of Article VI of the Outer Space Treaty in that state responsibility of a state also covers activities taking place under registration-based jurisdiction of that state, ${ }^{59}$ it would mean that any authorisation regime for private space activities would have to be extended to cover this category of activities.

From the other end, the registration of space objects may also result in states better being able to exercise jurisdiction over certain categories of space activities for the purposes of international responsibility as much as international liability than they might otherwise have been.

Imagine a state being used as launching territory by a satellite operator from a different state. The first state, through its territory, qualifies as a "launching State" of the satellite thus launched, under Article I(c), sub (ii) of the Liability Convention. If it conducts the launch itself, not only will it be liable under Article I(c), sub (i) of the Liability Convention, but it will also have concluded a launch contract with the satellite operator. If the actual launch has been conducted by a private launch service provider, it will have the competence, following from its territorial jurisdiction, to authorise that launch, refuse such authorisation, or impose conditions on such authorisation - and it will most probably do so in order to cover its liability under the Liability Convention.

Whichever of the two subscenarios would become reality, however, as soon as the satellite has separated from the launch vehicle and actual control of its operations has been taken over by a ground station of the operator, presumably outside of the territory of the first state, that state has no more legal control over the operator and its operations-yet remains liable basically until eternity as launching state: once a launching state, always a launching state; once liable, always liable.

Of course, that gap between continuing liability and lack of direct jurisdiction could be bridged to some extent through the aforementioned launch contract, respectively the requirement for the private launch service provider to include in the launch contract a provision, obliging the satellite operator to reimburse any international liability claim for the state concerned under the Liability Convention. Such clauses, however, may be hampered by their contractual nature and by being limited to liability issues.

A much more comprehensive approach therefore would be for the state concerned, as launching state, if necessary after consultation with other states qualifying as such, ${ }^{60}$ to insist on acting as state of registration under Article VIII and the Registration Convention and thereby continue to be entitled to exercise jurisdiction over the operations of the space object so registered, in order to control its international responsibilities and liabilities.

In conclusion, Article VIII of the Outer Space Treaty and the Registration Convention provide for a legal tool to be taken into consideration when implementing the authorisation requirement under Article VI of the Outer Space Treaty, being so closely related even as to likely have an effect of codetermining the scope of international responsibility for national activities under Article VI-although that ultimately would be a matter of national space law as the ultimate manifestation of state practice and opinio juris on this, in the absence of clear guidance on the international level. 


\section{Concluding Remarks}

Coming back to the issue of authorisation as originating in Article VI of the Outer Space Treaty, it is thus clear that beyond that basic level of positing the requirement, a number of key issues remain far from clarified at the international level. What is the exact scope of the international responsibility which any state carries under this key clause, as no doubt being that state's main concern in terms of implementing the authorisation requirement and using it for that purpose? To what extent would such authorisation then be able to cover also all possible situations where international liability, under the Liability Convention, may be claimed? What would be the ramifications of one state authorising, through registration of the space object, the operations undertaken therewith, on a quasi-national/ quasi-territorial basis, with another state authorising the operator of that subject to undertake such operations on the basis of national and/or territorial jurisdiction?

While experts have come up with various solutions on these issues, ultimately it is up to the states concerned to create the state practice and opinio juris which could lead to authoritative interpretations thereof. States, indeed, are confronted with the need to pick and choose from such various options once they are going to draft a national space law unless they would like the uncertainties existing on the international level to be transposed also to the national level, causing legal uncertainty with any prospective private entity interested in undertaking space activities. In view of the obvious negative consequences of the latter approach, states so interested would indeed be inclined to scope their national authorisation regimes quite precisely (a propos "national activities" of Article VI), to outline in detail what liability obligations authorised operations would entail (a propos the obligations under Article VII and the Liability Convention), and to precisely determine which space objects they wish to register nationally and internationally (a propos Article VIII and the Registration Convention).

Unfortunately, as will become clear in several of the other contributions to this book, individual states take individual approaches to the matter, making their own judgement on which activities they might be held responsible and/or liable for, and which activities they consequently aim to control in what manner. This obviously raises, at least in the European context, the question to which extent a measure of harmonisation of some key aspects of national authorisation, as per the European Space Agency or European Union, would be feasible, desirable, and workable.

\section{Notes}

1. See e.g. G. Zhukov \& Y. Kolosov, International Space Law (1984), esp. 4-17, 36; also P. Malanczuk, Actors: States, International Organizations, Private Entities, in G. Lafferranderie \& D. Crowther (Eds.), Outlook on Space Law over the Next 30 Years (1997), 30; S. Hobe, Die rechtlichen Rahmenbedingungen der wirtschaftlichen Nutzung des Weltraums (1992), 72; in more general terms M. N. Shaw, International Law (6th ed.)(2008), 31-36; M. Akehurst, A Modern Introduction to International Law (5th ed.)(1984), 16-19; A. Cassese, International Law (2001), 40. On the fundamental changes in 
this Soviet perspective due to "glasnost" and "perestroika," see V. S. Vereshchetin \& G. V. Silvestrov, Space Commercialization in the Soviet Union: Facts, Policy and Legal Issues, in K. Tatsuzawa (Ed.), Legal Aspects of Space Commercialization (1992), 32-40.

2. See Question of the peaceful use of outer space, UNGA Res. 1348 (XIII), of 13 December 1958; Resolutions adopted on the reports of the First Committee, General Assembly - Thirteenth Session, at 5 .

3. See International cooperation in the peaceful uses of outer space, UNGA Res. 1472 (XIV) A, of 12 December 1959; Resolutions adopted on the reports of the First Committee, General Assembly-Fourteenth Session, at 5 .

4. See Communications Satellite Act, Public Law 87-624, 87th Congress, H.R. 11040, 31 August 1962; 76 Stat. 419; as amended 1978; Space Law - Basic Legal Documents, E.III.2. This situation lasted for a number of decades, until in the 90s the privatisation process in the satellite communications sector (capped - as far as the United States is concerned-by the Open-market Reorganization for the Betterment of International Telecommunications Act, Public Law 108-180, 106th Congress, 17 March 2000) also resulted in the privatisation of Comsat.

5. Declaration of Legal Principles Governing the Activities of States in the Exploration and Use of Outer Space (hereafter Resolution 1962(VIII)), UNGA Res. 1962(XVIII), of 13 December 1963; UN Doc. A/AC.105/572/Rev. 1, at 37.

6. See Preamble, paras. 1, 2 \& 3, Resolution 1962(VIII).

7. E.g. Princ. 1 provides "the exploration and use of outer space shall be carried on for the benefit and in the interests of all mankind."

8. Emphasis added-twice.

9. It may be noted, that this was part of the general approach of communism to international law, fuelled no doubt by the relative feeling of isolation of the Soviet Union, that the international legal order recognised only completely sovereign entities called "states," which in their sovereignty could decide upon which rules they felt would and should be applicable to them. Concepts such as "international organisations" and "private entities," fundamentally alien to such an understanding of international law, were thus basically to be ignored; their activities for such purposes to be somehow attributed to a state or a set of states. Cf. also supra, n. 1 .

10. Princ. 5, Resolution 1962(XVIII).

11. Treaty on Principles Governing the Activities of States in the Exploration and Use of Outer Space, including the Moon and Other Celestial Bodies (hereafter Outer Space Treaty), London/Moscow/Washington, done 27 January 1967, entered into force 10 October 1967; 610 UNTS 205; TIAS 6347; 18 UST 2410; UKTS 1968 No. 10; Cmnd. 3198; ATS 1967 No. 24; 6 ILM 386 (1967).

12. Art. I, Outer Space Treaty (emphasis added).

13. Art. III, Outer Space Treaty (emphasis added).

14. Cf. e.g. Artt. IV, V, VIII-X, Outer Space Treaty.

15. See http://www.unoosa.org/oosa/en/SpaceLaw/treaties.html, accessed 16 February 2009. With regard to states that have signed but not yet ratified the Outer Space Treaty, it may further be noted that Art. 18(a), Vienna Convention on the Law of Treaties, May 23, 1969, 1155 U.N.T.S. 331 (commonly recognised as customary international law also for nonparty states), provides: "A State is obliged to refrain from acts which would defeat the object and purpose of a treaty when (...) it has signed the treaty or has exchanged instruments constituting the treaty subject to ratification, acceptance or approval, until it shall have made its intention clear not to become a party to the treaty." 
16. Though formally speaking states are equal under international law also in terms of the "value" of their partisanship to treaties, especially in the context of customary international law discussions it has been widely recognised that acceptance of international rights and obligations by certain states weighs more heavily than those by others if the former are geopolitically speaking more important and/or more representative of parts of the global community of states and/or more actively involved in the field under discussion. In other words, the fact that by and large all space-faring states are parties to the Outer Space Treaty and that, conversely, nonparties are largely to be found amongst smaller states not active as of yet in outer space certainly further enhances the validity of the treaty as a law-creating treaty. See further e.g. R. M. M. Wallace, International Law (3rd ed.)(1997), 10-12; Cassese, 119-24; Akehurst, 31-32.

17. Art. VI, Outer Space Treaty, inter alia reflected the general principle of state responsibility in international law in focusing on the occurrence of an international wrongful act (here referred to as anything not in "conformity with the provisions set forth in the present Treaty"). See on the general theory of state responsibility in international law e.g. Cassese, 182-211; Wallace, 173204. Furthermore, Art. III ensured that wherever the specifics of space law would not be clear enough for application of the concept, reference could be had to general international law.

18. See e.g. Cassese, 187-91; Wallace, 176-78.

19. Cf. once more Art. III, Outer Space Treaty, and its potential role in this context, as discussed supra, n. 17. For some discussion on what constitute "national activities" see e.g. F. G. von der Dunk, Private Enterprise and Public Interest in the European 'Spacescape' (1998), 18-19; H. A. Wassenbergh, Principles of Outer Space Law in Hindsight (1991), $23 \mathrm{ff}$.

20. Agreement Governing the Activities of States on the Moon and Other Celestial Bodies (hereafter Moon Agreement), New York, done 18 December 1979, entered into force 11 July 1984; 1363 UNTS 3; ATS 1986 No. 14; 18 ILM 1434 (1979). Amongst the European states, only Austria, Belgium, and the Netherlands are amongst the thirteen parties to the Agreement, whereas France has signed but not ratified it. See for the details on ratification and signature of the Moon Agreement the website of the UN Office for Outer Space Affairs (OOSA), at http://www.unoosa.org/ oosa/en/SpaceLaw/treaties.html.

21. Art. 14(1), Moon Agreement.

22. Art. 14(1), Moon Agreement (emphasis added).

23. This applies in particular to the issue of "prior consent" under UNGA Resolution 37/92; see infra, n. 24.

24. Principles Governing the Use by States of Artificial Earth Satellites for International Direct Television Broadcasting, UNGA Res. 37/92, of 10 December 1982; UN Doc. A/AC.105/572/Rev.1, at 39.

25. Emphasis added.

26. Princ. 5, UNGA Res. 37/92. Cf. also Princ. 1, UNGA Res. 37/92, providing for general application of the Outer Space Treaty, including of course Article VI, to the Resolution's subject matter.

27. Principles Relating to Remote Sensing of the Earth from Outer Space, UNGA Res. 41/65, of 3 December 1986; UN Doc. A/AC.105/572/Rev.1, at 43; 25 ILM 1334 (1986).

28. Princ. XIV, UNGA Res. 41/65; emphasis added. See further S. Gorove, Developments in Space Law (1991), 294-97, 304-10; K. Tatsuzawa, Policy and Law in Space Commercialization, in K. Tatsuzawa (Ed.), Legal Aspects of Space Commercialization (1992), 24.

29. See e.g. Wassenbergh, 23; B. Cheng, The Commercial Development of Space: the Need for New Treaties, 19 Journal of Space Law (1991), 36-40; H. Qizhi, Certain Legal Aspects of Commercialization of Space Activities, 15 Annals of Air and Space Law (1990), 337; D. H. Kim, A Commentary 
to the Article VI of the Outer Space Treaty, Proceedings of the United Nations/Republic of Korea Workshop on Space Law (2004), 79-80; H. L. van Traa-Engelman, Commercial Utilization of Outer Space (1993), 61, 281-82.

30. Art. IX, Outer Space Treaty, provided in relevant part: "If a State Party to the Treaty has reason to believe that an activity or experiment planned by it or its nationals in outer space (...) would cause potentially harmful interference with activities of other States Parties (. . .) it shall undertake appropriate international consultations before proceeding with any such activity or experiment" (emphasis added), equating a state's activities to those of its nationals for the limited purpose of this clause.

31. See further infra, section 5, for a discussion on the relationship between Art. VI, Outer Space Treaty, and Art. VII.

32. The fourfold definition of Art. VII (see infra, section 5, text at n. 45, for text of Art. VII) was later formalised through the concept of the "launching State" introduced by the Convention on International Liability for Damage Caused by Space Objects (hereafter Liability Convention), London/Moscow/Washington, done 29 March 1972, entered into force 1 September 1972; 961 UNTS 187; TIAS 7762; 24 UST 2389; UKTS 1974 No. 16; Cmnd. 5068; ATS 1975 No. 5; 10 ILM 965 (1971). Art. I(c), Liability Convention, defined the "launching State" as: "(i) A State which launches or procures the launching of a space object; (ii) A State from whose territory or facility a space object is launched."

33. See for a broader analysis of these issues, and others pertinent to the responsibility-liability relationship, F. G. von der Dunk, Liability versus Responsibility in Space Law: Misconception or Misconstruction?, in Proceedings of the Thirty-Fourth Colloquium on the Law of Outer Space (1992), $363-71$.

34. See e.g. I. Brownlie, Principles of Public International Law (7th ed.)(2008), 105-6, 301-3; M. N. Shaw, International Law (6th ed.)(2008), 652-58; Wallace 112-14; Cassese, 55-63.

35. See e.g. Brownlie, 303-4; Shaw, 659-66; Wallace 114-15.

36. The concept of "extradition" was developed in the traditional international discourse on national criminal law, to solve cases where one state was interested in prosecuting a crime or seeking enforcement of punishment duly arrived at by its judiciary system, presumably where its courts had jurisdiction over the matter, but the persons concerned were not present on the territory of that state (read: within its territorial jurisdiction) so that actual enforcement was dependent upon the exercise of territorial jurisdiction by the states where such persons were present. See e.g. Shaw, 686-87; Brownlie, 316-18; Akehurst, 104-7; Wallace, 119-21. From the present perspective, this would include cases where the latter states were, in themselves, also entitled to exercise jurisdiction but rightly or wrongly perceived the former state to have the stronger or more appropriate basis for exercising its criminal jurisdiction.

37. Forum non conveniens is a concept entitling courts of one state to desist from exercising jurisdiction to try a case mainly because such courts perceive another jurisdiction to be the more appropriate one to do so. See e.g. Wallace, 111; P. M. North \& J. J. Fawcett, Private International Law (13th ed.)(2004), 334-35; cf. also Brownlie, 300; Shaw, 646-67.

38. The traditional concept of "diplomatic immunity" from this perspective may be described as a tool to invert the traditional hierarchical superiority of territorial jurisdiction of one state over the personal jurisdiction of another for the sake of diplomatic relations, and limited for that reason to diplomatic envoys and premises, whose presence on the territory of the host state would otherwise make them subject first and foremost to that state's territorial jurisdiction as opposed to the personal jurisdiction of the sending state. See e.g. Akehurst, 111-17; Wallace, 124-33; Cassese, 90-96; Shaw, $750 \mathrm{ff}$. 
39. In the famous Barcelona Traction Case (Case Concerning the Barcelona Traction Light and Power Company, Limited (Second Phase)(Belgium v. Spain), International Court of Justice, 5 February 1970, I.C.J. Rep. 1970, 4), the International Court of Justice referred to the place(s) of incorporation and headquarters as the decisive criterion/criteria to allocate limited liability companies to one particular state for the purpose of exercising international diplomatic protection. Since then, however, a number of court cases and arbitral awards-such as in the context of the Iran-United States Claims Tribunal-have put the general applicability of this approach in doubt. See e.g. Brownlie, 419-21, 482-90; Shaw, 815-18; Akehurst, 99; Wallace, 192-94.

40. Art. VIII, Outer Space Treaty. See for a further discussion of this Article, as elaborated moreover by the Convention on Registration of Objects Launched into Outer Space (hereafter Registration Convention), New York, done 14 January 1975, entered into force 15 September 1976; 1023 UNTS 15; TIAS 8480; 28 UST 695; UKTS 1978 No. 70; Cmnd. 6256; ATS 1986 No.5; 14 ILM 43 (1975), infra, section 6.

41. See especially infra, the contributions of I. Marboe \& F. Hafner; J. F. Mayence.

42. The present author made the argument that indeed the possible multiplicity of responsible states was not negated by the explicit singular of "the appropriate state," and that at the same time the latter concept was to guarantee that whilst many states might be held responsible in applicable cases, at least one was to be singled out as obliged to actually implement such international responsibility by means of concrete procedures and rules for authorisation (and continuing supervision); see Private Enterprise and Public Interest in the European 'Spacescape' - Towards Harmonized National Space Legislation for Private Space Activities in Europe, 20-21.

43. See on these key concepts in the context of development of customary international law e.g. Cassese, 119-23; Wallace, 14-19; Shaw, 72-89; Brownlie, 7-10.

44. Art. IX runs in relevant part: "States Parties to the Treaty shall (. . .) conduct exploration of them so as to avoid their harmful contamination and also adverse changes in the environment of the Earth resulting from the introduction of extraterrestrial matter and, where necessary, shall adopt appropriate measures for this purpose. If a State Party to the Treaty has reason to believe that an activity or experiment planned by it or its nationals in outer space, including the Moon and other celestial bodies, would cause potentially harmful interference with activities of other States Parties in the peaceful exploration and use of outer space, including the Moon and other celestial bodies, it shall undertake appropriate international consultations before proceeding with any such activity or experiment. A State Party to the Treaty which has reason to believe that an activity or experiment planned by another State Party in outer space, including the Moon and other celestial bodies, would cause potentially harmful interference with activities in the peaceful exploration and use of outer space, including the Moon and other celestial bodies, may request consultation concerning the activity or experiment."

45. As indicated supra, n. 32, the Liability Convention formalised this fourfold criterion for attributing liability for damage caused by space objects by introducing the concept of the "launching State"; cf. Art. I(c).

46. For those further interested in the author's views on this, reference may be had to Liability versus Responsibility in Space Law: Misconception or Misconstruction?, see supra, n. 33.

47. See supra, n. 32 and accompanying text.

48. By contrast, a state might be "responsible" for such damage under Art. VI, Outer Space Treaty, only if it resulted from a "national activity" and comprised, in itself, a violation of the Outer Space Treaty's regime.

49. The latter argument could be supported by "transplanting" the fundamental legal equality between governmental and nongovernmental activities as propounded by Art. VI, Outer Space 
Treaty (see also supra, discussion at n. 18), to Art. VII (and the Liability Convention), inferring that references to "a state" anywhere in the Outer Space Treaty always includes the private entities somehow subsumed under it.

50. See e.g. Shaw, 487 ff.; Brownlie, 105 ff.; Cassese, 48, 56 ff.; Wallace, 92-93; also K. H. Böckstiegel, The Term 'Launching State' in International Space Law, Proceedings of the Thirty-Seventh Colloquium on the Law of Outer Space (1995), 82.

51. So A. Kerrest de Rozavel, Launching Spacecraft from the Sea and the Outer Space Treaty: The Sea Launch Project, Proceedings of the Fortieth Colloquium on the Law of Outer Space (1998), esp. $267-78$.

52. See Kerrest de Rozavel, 265-66, 268; Shaw, 609 ff.; Brownlie, 223 ff.; Cassese, 60-61; Wallace, $148-49$.

53. See e.g. M. Gerhard, The State of the Art and Recent Trends in the Development of National Space Law, in C. Brünner \& E. Walter (Eds.), Nationales Weltraumrecht/National Space Law (2008), 67-68; M. Chatzipanagiotis, Registration of Space Objects and Transfer of Ownership in Orbit, 56 Zeitschrift für Luft-und Weltraumrecht (2007), 235; Böckstiegel, 81-82; on the various interpretations possible of "procurement" in this context.

54. Sec. 1(a), Outer Space Act (hereafter UK Outer Space Act), 18 July 1986, 1986 Chapter 38; National Space Legislation of the World, Vol. I (2001), at 293; Space Law-Basic Legal Documents, E.I; 36 Zeitschrift für Luft-und Weltraumrecht (1987), at 12; provides that "This Act applies to the following activities whether carried on in the United Kingdom or elsewhere (...) procuring the launch of a space object," whereas Sec. 13(2) provides that "For the purposes of this Act a person carries on an activity if he causes it to occur or is responsible for its continuing." See further e.g. J. A. Ballard, The UK Outer Space Act 1986 and nongovernmental activities in the United Kingdom, paper presented at the 4th Dutch NPOC/ECSL Workshop, Noordwijk, December 1995.

55. Cf. e.g. G. Lafferranderie, Jurisdiction and Control of Space Objects and the Case of an International Intergovernmental Organization (ESA), 54 Zeitschrift für Luft-und Weltraumrecht (2005), 228-29; Y. Zhao, Revisiting the 1975 Registration Convention: Time for Revision?, in Proceedings of the United Nations/Republic of Korea Workshop on Space Law (2004), 127; C. Q. Christol, The Modern International Law of Outer Space (1982), e.g. 218-23.

56. Art. 1I(2), Registration Convention.

57. See supra, text at nn. $34 \& 35$, and accompanying references.

58. One could argue that either national jurisdiction is applied on a quasi-national basis to registered space objects, which by token of their registration have been given the quasi-nationality of the state claiming and/or exercising such jurisdiction, or territorial jurisdiction is applied on a quasiterritorial basis to such space objects, which by their registration have been transformed into quasi-territory of the state claiming and/or exercising such jurisdiction, but this is essentially a theoretical point. See further Private Enterprise and Public Interest in the European 'Spacescape' Towards Harmonized National Space Legislation for Private Space Activities in Europe, 27-31.

59. See on this discussion supra, at n. 40.

60. See Art. II(2), Registration Convention, as quoted supra. 